\title{
Individual cell DNA synthesis within natural marine bacterial assemblages as detected by 'click' chemistry
}

\author{
Steven Smriga $^{1,2, *}$, Ty J. Samo ${ }^{1,3}$, Francesca Malfatti ${ }^{1,4}$, Joseph Villareal ${ }^{1}$, \\ Farooq Azam ${ }^{1}$
}

${ }^{1}$ Marine Biology Research Division, Scripps Institution of Oceanography, University of California San Diego, La Jolla, California 92093-0202, USA

\footnotetext{
${ }^{2}$ Present address: Department of Civil and Environmental Engineering, Massachusetts Institute of Technology, Cambridge, Massachusetts 02139, USA

${ }^{3}$ Present address: Center for Microbial Oceanography: Research \& Education (C-MORE), Department of Oceanography, University of Hawaii at Manoa, Honolulu, Hawaii 96822, USA

${ }^{4}$ Present address: OGS (National Institute of Oceanography and Experimental Geophysics) Oceanography Section (OCE), 34151 Santa Croce, Trieste, Italy
}

\begin{abstract}
Individual cell growth rates enhance our understanding of microbial roles in regulating organic matter flux in marine and other aquatic systems. We devised a protocol to microscopically detect and quantify bacteria undergoing replication in seawater using the thymidine analog 5-ethynyl-2'-deoxyuridine (EdU), which becomes incorporated into bacterial DNA and is detected with a 'click' chemistry reaction in $<1 \mathrm{~h}$. Distinct EdU localization patterns were observed within individual labeled cells, e.g. some displayed 2 or more distinct EdU loci within a single DAPIstained region, which likely indicated poleward migration of nascent DNA during the early phase of replication. Cell labeling ranged from 4.4 to $49 \%$, comparable with cell labeling in parallel incubations for ${ }^{3} \mathrm{H}$-thymidine microautoradiography. Meanwhile, EdU signal intensities in cells ranged $>3$ orders of magnitude, wherein the most intensely labeled cells comprised most of a sample's sum community EdU signal, e.g. $26 \%$ of cells comprised $80 \%$ of the sum signal. This ability to rapidly detect and quantify signals in labeled DNA is an important step toward a robust approach for the determination of single-cell growth rates in natural assemblages and for linking growth rates with microscale biogeochemical dynamics.
\end{abstract}

KEY WORDS: Single cell growth · Click chemistry · Marine bacteria · Microradiography · Epifluorescence microscopy $\cdot \operatorname{BrdU}$

\section{INTRODUCTION}

Through individual cell interactions at the microscale, marine bacteria contribute to organic matter fluxes and elemental cycling at the ocean basin scale (Azam \& Malfatti 2007). Our conceptual understanding of the role of microbial dynamics in regulating organic matter flux is continually strengthened by the development and use of techniques that detect and quantify individual-cell activities and growth at microscale resolution (del Giorgio \& Gasol 2008). Metabolic activities that can currently be detected in individual cells include respiration and esterase activity; and viable cells can be detected using live and dead stains, nalidixic acid, and observations of cultivatable microcolonies on agar plates. These and other methods have revealed the potential for high variability in cell-specific metabolism within bacterioplankton assemblages (del Giorgio \& Gasol 2008). 
A challenge to the field of microbial oceanography is the quantification of individual bacteria cell growth rates by methods that are applicable in a range of field settings. One approach is the detection of incorporated tritiated thymidine $\left({ }^{3} \mathrm{H}-\mathrm{TdR}\right)$ via microautoradiography (Fuhrman \& Azam 1982, Douglas et al. 1987). While this method has been used in microbial oceanography for several decades and has yielded important insights, its use is often limited by regulatory restrictions, especially in remote locations and other field settings. An alternative non-radioisotopic approach is based on incorporation of the TdR analog 5-bromo-2'-deoxyuridine (BrdU) (Steward \& Azam 1999). Some studies coupled BrdU immunochemical detection with fluorescence in situ hybridization (FISH) to detect the phylogenetic affiliation of growing bacteria cells in coastal seawater (Pernthaler et al. 2002, Tada et al. 2011). Another study optimized BrdU detection in marine bacteria and observed a positive correlation between growth rates and fluorescence intensity of growing cells (Hamasaki et al. 2004). Similar to microradiography, immunochemical detection of BrdU, as used in these studies, is a relatively low throughput technique because it requires multiple processing steps, including cell permeabilization, DNA denaturation, probing with anti-BrdU antibodies, and signal amplification via catalyzed reporter deposition.

Recently, a method that uses 5-ethynyl-2'-deoxyuridine (EdU) was developed as an alternative to ${ }^{3} \mathrm{H}$ TdR and BrdU in cell biology (Salic \& Mitchison 2008). Similar to BrdU, EdU acts as an analog for TdR. Incorporated EdU is detected in cells by 'ligating' it with a fluorescent azide through a copper(I)catalyzed alkyne-azide cycloaddition; this is a specific type of 'click' reaction that we henceforth simply call 'click reaction' (Kolb et al. 2001, Rostovtsev et al. 2002). The relatively small sizes of molecules used in click reactions permit penetration through many eukaryotic cell membranes and eliminate the need for DNA denaturation, antibody probing, or signal amplification.

Here we report the use of EdU to detect natural populations of DNA-synthesizing bacteria in coastal seawater. We optimized the method for microscopic detection and summarize the parameters that were compared during this optimization. We then quantified the dynamic range of single bacteria cell fluorescence intensities in natural bacterial assemblages, a critical step toward a robust approach in the future for the determination of single cell growth rates in marine microbes and for linking growth rates with microscale biogeochemical dynamics in the ocean.

\section{MATERIALS AND METHODS}

\section{Application of click reaction chemistry for detection of EdU}

Three types of filter membranes (25 mm diameter, $0.2 \mu \mathrm{m}$ pore size) were tested for collecting formaldehyde-fixed seawater bacteria and subsequent treatment with click chemistry: white polycarbonate (Millipore, GTTP02500), black polycarbonate (Millipore, GTBP02500), and Anodisc aluminum oxide (Whatman, 6809-6022). The Anodisc membranes were adopted for use (see supplementary 'Materials and methods' at www.int-res.com/articles/suppl/a072p269 _supp.pdf for further details). After filtration, onequarter-sized membrane sections were removed for click reactions, with the remainder stored at $-20^{\circ} \mathrm{C}$ for future analyses.

Two different cell permeabilization treatments were tested on filter membranes. One was lysozyme incubation $\left(50 \mathrm{mg} \mathrm{ml}^{-1}\right.$ in TE buffer [10 mM Tris, $1 \mathrm{mM}$ EDTA, pH 7.5], $30 \mathrm{~min}, 37^{\circ} \mathrm{C}$ ). The other was pepsin incubation $\left(2 \mathrm{mg} \mathrm{ml}^{-1}\right.$ in $0.01 \mathrm{~N} \mathrm{HCl}, 2 \mathrm{~h}, 37^{\circ} \mathrm{C}$ ) followed by lysozyme incubation $\left(3 \mathrm{mg} \mathrm{ml}^{-1}\right.$ in TE buffer, $15 \mathrm{~min}, \sim 21^{\circ} \mathrm{C}$ ). The treatments were tested because some fluorescent azides are not readily permeable in eukaryotic cells, and these cells required additional permeabilization prior to incubation with fluorescent azides (Salic \& Mitchison 2008). However, our tests demonstrated that a permeabilization step was not necessary for marine bacteria (see supplementary 'Materials and methods' for further details).

All tests of EdU detection were performed using the Click-iT EdU AlexaFluor High-Throughput Imaging Assay kit (Invitrogen, Cat. No. A10027). The kit includes EdU, AlexaFluor-488 azide, reaction buffer, $\mathrm{CuSO}_{4}$, and reaction buffer additive. Reagents were distributed and stored according to the manufacturer's recommendations. The 'buffer additive' component of the reaction mixture was added to the reaction cocktail just prior to use. AlexaFluor-488 azide was used throughout this study, though other fluorophore azides are available.

Among 4 protocols tested for applying click reaction cocktail, a 'coverslip-inversion' method using ethanol-washed coverslips was adopted (for description of non-adopted protocols see supplementary 'Materials and methods'). For each sample, a portion of filter membrane was placed onto a clean glass slide with cell side facing up. Glass cover slips (Corning, $25 \times 25 \mathrm{~mm}$, Part No. 2870-25) were washed with $70 \%$ ethanol and thoroughly dried. The reaction 
cocktail was prepared on ice according to the manufacturer's instructions, but volumes were adjusted accordingly depending on the number of filter pieces to be processed. For a one-quarter section of $25 \mathrm{~mm}$ membrane, $25 \mu$ reaction cocktail was sufficient and more cost effective. (The cost per sample was $\$ 0.90$ for the chemistry assuming $25 \mu$ reaction cocktail per sample.) The cocktail was spotted onto a cover slip and inverted onto the membrane piece on the slide; thus, cells were sandwiched between membrane and cover slip. The slide was placed horizontally into an incubation chamber that consisted of a $50 \mathrm{ml}$ disposable plastic tube (Falcon ${ }^{\circledR}$ ) containing a tissue paper (Kimwipe ${ }^{\circledR}$ ) soaked with deionized water. The slide chamber was incubated in the dark for $30 \mathrm{~min}$ at $\sim 21^{\circ} \mathrm{C} ; 30 \mathrm{~min}$ incubations were used for all tests, but it may be possible to shorten the incubation without compromising cell signal intensity.

\section{Cell counterstaining and microscopy slide preparation}

Following application of the click reaction, membrane sections were removed from the slide using forceps, dipped sequentially into 2 dishes of autoclaved distilled water for $\sim 2 \mathrm{~s}$ per bath, washed for $3 \mathrm{~min}$ in autoclaved distilled water in the dark, and then set momentarily sample side up on tissue paper to wick away excess fluid; drying to completion was not necessary. Membranes were then placed sample side up onto a $10 \mu \mathrm{l}$ drop of DAPI $\left(1 \mu \mathrm{g} \mathrm{m} \mathrm{m}^{-1}\right)$, incubated in the dark for $5 \mathrm{~min}$ at $\sim 21^{\circ} \mathrm{C}$, rinsed as above, and then dried to completion at $37^{\circ} \mathrm{C}$ for 3 to $4 \mathrm{~min}$. Oven drying was achieved more rapidly for some Anodisc membrane pieces by carefully mounting them vertically into office binder clips via their plastic support ring. Dried membranes were then mounted to slides using a glycerol-based anti-fading formulation (1:1 glycerol and phosphate-buffered saline (PBS) with $0.1 \% \mathrm{w} / \mathrm{v}$ phenylenediamine; Noble \& Fuhrman 1998). Next, $10 \mu$ l of mountant was spotted onto the slide, the dry filter piece was placed sample side up atop the mountant, and a coverslip containing another $10 \mu \mathrm{l}$ of mountant was placed onto the filter piece. Other counterstaining techniques were tested but not adopted (see supplementary 'Materials and methods'). Importantly, membranes were viewed or imaged within $2 \mathrm{~h}$ of slide mounting due to observed confounding effects between copper and DAPI counterstaining; thus, we prepared filter pieces in groups of 3 to 4 at a time (see supplementary 'Materials and methods'). We observed EdU- labeled cells on membranes that had been stored dry for at least $18 \mathrm{mo}$ at $-20^{\circ} \mathrm{C}$.

\section{Microscopy and image analysis}

Image capture and analyses were controlled with the software package NIS Elements AR 3.0 (SP 1) connected to a Nikon Eclipse TE-2000 inverted epifluorescence microscope equipped with a $100 \times$ objective, a monochrome CoolSNAP HQCCD camera (Roper Scientific), and adaptable fluorescence filter sets. Peak channel excitation and emission wavelength/bandpass in nm were 350/50ex and 457/50em for blue (DAPI), 490/20ex and 528/38em for green (EdU conjugated with AlexaFluor-488), and 555/28ex and 617/73em for red (autofluorescent photopigments). Exposure times were kept constant at $500 \mathrm{~ms}$ (blue and green) and $1 \mathrm{~s}$ (red) for all filters. Multichannel images (blue, green, and red) were collected for 10 to 20 haphazardly selected fields on each filter membrane. To enumerate cells from each image, intensity thresholding was applied to the blue channel to create a cell binary layer. The binary was overlayed onto the red channel to remove autofluorescent picoplankton (Synechococcus and picophytoeukaryotes, generally 0 to 10 cells per image) since pigments from these cells displayed a crossover signal in the green channel. The resulting binary was used to quantify total cells. Size restrictions were gated such that the lower limit on cell area was always $0.02 \mu \mathrm{m}^{2}$ while the upper limit varied by image (generally 3.0 to $5.0 \mu^{2}$ ) to exclude protists and amorphous particles.

To quantify EdU signal intensities (i.e. AlexaFluor488 azide), the constructed binary layer was overlaid onto the green channel image, and data were exported for each cell including 'area' (as $\mu \mathrm{m}^{2}$, which was converted to pixels) and 'sum intensity' (i.e. the integrated intensity for all pixels within a given cell). Also exported from each green channel image was the 'whole image mean pixel intensity' or WIMPI (i.e. the mean intensity for all pixels in an image including both cellular and empty space on the filter membrane). From these data, the following 2 parameters were calculated for each cell: 'background sum intensity' or BSI (i.e. the product of WIMPI and cell pixel area), and 'EdU signal intensity' or ESI (i.e. the 'sum intensity' minus BSI). A cell was scored as 'labeled' if ESI was $>110 \%$ of WIMPI. In other words, a cell was considered labeled if its integrated green intensity was $>10 \%$ above the background signal inherent to its area. 


\section{Labeling growing cultured cells and testing EdU-TdR competition}

Tests of cell labeling in growing cultured isolates were designed following similar studies of $\mathrm{BrdU}$ incorporation (Hamasaki et al. 2004). Briefly, 4 marine isolates (Table $\mathrm{S} 2$ in the Supplement) were grown for $2 \mathrm{~d}$ in seawater medium (SWMi Steward \& Azam 1999). An aliquot of each culture was inoculated into duplicate tubes of $8 \mathrm{ml}$ fresh SWM and incubated for $2 \mathrm{~h}$ at $\sim 21^{\circ} \mathrm{C}$. The labeling experiment was then started by amending cultures with EdU $(1 \mu \mathrm{M})$. Subsamples $(1 \mathrm{ml})$ were collected at $0,2,5$, and $9 \mathrm{~h}$ and fixed with $2 \%$ formaldehyde final concentration. Aliquots of the subsamples $(0.1 \mathrm{ml})$ were collected onto Anodisc filters, rinsed with $2 \mathrm{ml}$ PBS, dried, and stored at $-20^{\circ} \mathrm{C}$ until processing. Filters for the $5 \mathrm{~h}$ time point were processed to determine EdU cell labeling as described above. Total cell abundance was determined for all time points using separate filter pieces that were DAPI-stained without click reaction processing, and the specific growth rate of each isolate was estimated using the abundance results. A follow-up experiment on isolate SBD8 tested whether EdU incorporation was limited to growing cells. The test was the same as above but included a formaldehyde-fixed incubation and live (non-fixed) cells incubated on ice.

To test EdU and TdR incorporation competition (i.e. whether EdU is incorporated through the same uptake and incorporation system as TdR), the 4 marine isolates were grown in SWM for $2 \mathrm{~d}$ and then transferred into fresh medium for $2 \mathrm{~h}$, as above. Duplicate culture aliquots were then amended with EdU alone $(20 \mathrm{nM})$, or co-amended with thymidine $(1 \mu \mathrm{M})$ and EdU $(20 \mathrm{nM})$. This high molar ratio of 50:1 was used to detect inhibition even if thymidine had much lower affinity for uptake and incorporation than EdU. Subsamples were collected at $5 \mathrm{~h}$ and then fixed and processed to determine percentage cell labeling, as above.

\section{Labeling in natural assemblages and comparison with ${ }^{3} \mathrm{H}$-TdR microradiography}

Seawater was collected on different dates from Scripps Pier or an offshore station (Table S1 in the Supplement). One sample was part of an experiment testing potential inhibitory effects of EdU on cell production (see supplementary 'Materials and methods'), which was also used to quantify individual cell signal intensity over $9 \mathrm{~h}$. Four samples were com- pared in parallel with microradiography (described below). In all cases, seawater aliquots were dispensed and either amended with EdU $(1 \mu \mathrm{M})$ or remained as unamended controls. Bottles were incubated 5 to $9 \mathrm{~h}$ before subsamples were removed, preserved with formaldehyde ( $2 \%$ final), and chilled to $4^{\circ} \mathrm{C}$. After $15 \mathrm{~min}$ fixation, $2 \mathrm{ml}$ was collected onto membrane filters, rinsed with $2 \mathrm{ml}$ PBS, dried, and stored at $-20^{\circ} \mathrm{C}$ until processing. The click reaction was performed on membrane filters as described above.

The EdU method and ${ }^{3} \mathrm{H}-\mathrm{TdR}$ microradiography were compared in parallel incubations of coastal seawater from the Scripps Pier and at an offshore station (Table S1 in the Supplement). Seawater was dispensed into duplicate $15 \mathrm{ml}$ tubes (Falcon), amended with $1.0 \mu \mathrm{M}$ EdU or $20 \mathrm{nM}^{3} \mathrm{H}$-thymidine, and incubated for $5 \mathrm{~h}(\mathrm{EdU})$ or $1 \mathrm{~h}\left({ }^{3} \mathrm{H}-\mathrm{TdR}\right)$ at $20^{\circ} \mathrm{C}$. The concentration and incubation time for EdU were selected based on previous studies of BrdU (Steward \& Azam 1999, Hamasaki et al. 2004), while those for ${ }^{3} \mathrm{H}-\mathrm{TdR}$ were based on previous radiotracer studies (e.g. Fuhrman \& Azam 1982, Steward \& Azam 1999, Cottrell \& Kirchman 2003). Subsamples were preserved as above and $2 \mathrm{ml}$ was collected onto Anodisc (EdU) or polycarbonate $\left({ }^{3} \mathrm{H}\right.$-TdR) membranes. EdU-labeled cells were detected and enumerated as described above. Membranes containing ${ }^{3} \mathrm{H}$-thymidine-labeled cells were processed for microradiography following methods previously described (Sintes \& Herndl 2006, Longnecker et al. 2010) with the following modifications: (1) filters were exposed to emulsion for $3 \mathrm{~d}$; (2) filter membrane fragments were removed from dried slides prior to processing with fixative and developer, which prevented separation of the emulsion layer from the glass slide; and (3) the darkroom lamp (Kodak GBX-2 safelight with a $15 \mathrm{~W}$ bulb) was placed $\sim 5 \mathrm{~m}$ from the sample preparation area and night vision goggles were worn, which permitted low background of photographic crystal development. Cells were enumerated from 10 to 20 microscopy fields each for duplicate EdU filters and duplicate ${ }^{3} \mathrm{H}$ TdR filters.

\section{RESULTS AND DISCUSSION}

Several parameters were tested to optimize the click reaction for microscopic detection of EdUlabeled bacteria, including filter membrane type, cell permeabilization, application of the click chemistry reaction cocktail, and fluorescence counterstaining (see supplementary 'Materials and methods'). Based 


\section{Sampling day \\ 1) Incorporate EdU: Incubate water sample with $1 \mu \mathrm{M}$ EdU \\ ( 3 to $7 \mathrm{~h}$ in dark) at in situ temperature.}

2) Stop incorporation: Fix sample with formaldehyde (f.c. 2\%) and filter onto $0.2 \mu \mathrm{m}$ Anodisc membrane. Proceed to step 3 or store membranes at $-20^{\circ} \mathrm{C}$ (e.g. up to $18 \mathrm{mo}$ ).

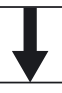

In laboratory

3) Perform 'click' reaction: Apply reaction cocktail via coverslipinversion method (30 min in dark). Rinse in water $(2 \times 2 \mathrm{~s})$ then wash in water (1 $\times 3$ min in dark).

Reaction cocktail components (\% by volume): water (77.5\%), reaction buffer (10\%), $\mathrm{CuSO}_{4}$ (2\%), AlexaFluor488-azide (0.5\%), and buffer additive (10\%).

4) Counterstain with DAPI: Apply DAPI $\left(1 \mu \mathrm{g} \mathrm{ml} l^{-1}\right)$ via membrane profusion method ( $5 \mathrm{~min}$ in dark). Rinse in water $(2 \times 2 \mathrm{~s})$ then wash in water ( $1 \times 3$ min in dark).

5) Dry to completion: (in dark; room temp or $37^{\circ} \mathrm{C}$ )

6) Prepare microscopy slide: prepare antifade solution; mount membrane to slide with antifade solution.

7) Imaging: capture images with cooled CCD camera within $2 \mathrm{~h}$ of slide preparation; capture blue (DAPI), green (AlexaFluor 488 indicating EdU), and red (autofluorescent pigment) channels.

Fig. 1. Overview of protocol for 5-ethynyl-2'-deoxyuridine (EdU) incorporation into marine bacteria and detection using 'click' reaction chemistry

on the results, a protocol was adopted for detection of EdU-labeled cells on Anodisc membrane filters without the need for cell permeabilization (Fig. 1). Importantly, processing for the visualization of EdUlabeled cells can be completed within $1 \mathrm{~h}$. Image analysis permits individual cell signal quantification, and here we defined 'labeled' cells as those that displayed an EdU signal $>10 \%$ above a background threshold.

The method was tested on 4 marine bacterial isolates growing in a seawater medium. Three isolates (Vibrio corallilyticus, Flexibacter sp. SBD8, Roseobacter sp. BBAT1) became labeled during growth over $5 \mathrm{~h}$ in $20 \mathrm{nM}$ EdU, with signals appearing at $\geq 2 \mathrm{~h}$ incubation and cell labeling ranging from 96 to $100 \%$ (Table S2 in the Supplement). Cytophaga SB19 did not become labeled; the reason for this is unclear but we speculate that it may be due to taxonomic affiliation. For all of the isolates, there was no labeling in treatments that contained EdU $(20 \mathrm{nM})$ in the presence of excess TdR ( $1 \mu \mathrm{M}$ or $50 \times$ higher concentration than EdU). The preferential incorporation of TdR confirmed that EdU acted as a specific analog for TdR for seawater bacteria, consistent with its use as a TdR analog in eukaryotic cell studies (e.g. Salic \& Mitchison 2008). In a separate test using Flexibacter sp. SBD8, labeling did not occur in formaldehyde-fixed cells or live cells incubated on ice, thus non-replicating cells in the ocean should not become labeled.

On incorporation, EdU has the potential to inhibit growth since it partially or completely replaces thymine in the DNA of replicating cells. To test this, we measured protein production and cell abundances in coastal seawater in the presence of $20 \mathrm{nM}$ to $1 \mu \mathrm{M}$ EdU over $24 \mathrm{~h}$ (see supplementary 'Materials and methods' for experimental details). Production rates were similar to unamended controls for all EdU concentrations over $7 \mathrm{~h}$, and cell abundances remained constant over the same interval (Fig. S1 in the Supplement). Notably, protein production and abundances were 10 to $30 \%$ lower than parallel unamended controls after $24 \mathrm{~h}$ incubation (data not shown), which suggests that some inhibition may occur over long exposure. Thus, incubations up to $7 \mathrm{~h}$ at concentrations up to $1 \mu \mathrm{M}$ EdU should not affect growth. In an incubation time course of coastal seawater, individual cell EdU signal intensity increased over $5 \mathrm{~h}$ with no additional per-cell intensity gain thereafter (Fig. 2), consistent with previously reported results for ${ }^{3} \mathrm{H}$-TdR incubations (Pedros-Alio \& Newell 1989). While the time course of incorporation should be tested for different environmental provinces, an incubation time of 3 to $7 \mathrm{~h}$ is recommended as a starting point for natural assemblages.

Our optimization demonstrates that the method's success in labeling natural assemblages of coastal seawater bacteria (Fig. 3) depends on 3 key require-

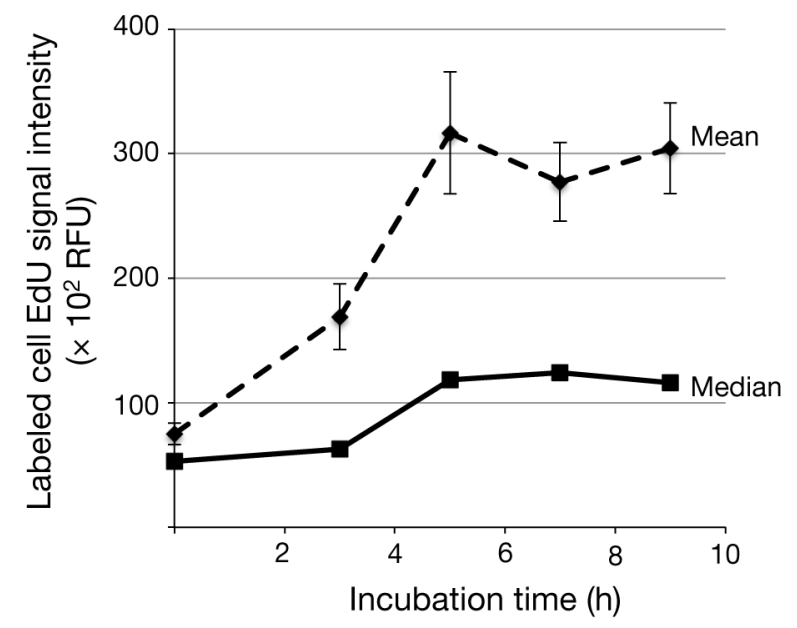

Fig. 2. Incubation time course showing mean and median 5-ethynyl-2'-deoxyuridine (EdU) signal intensities for individual labeled cells in EdU-amended seawater sample SP1. Error bars show \pm SE. The number of labeled cells analyzed was 95, 192, 216, 247, and 232 for, respective incubation times between 0 to $9 \mathrm{~h}$. For unamended controls (not shown), median values $\left(\times 10^{2} \mathrm{RFU}\right)$ were 21 at $0 \mathrm{~h}$ and 16 at $9 \mathrm{~h}$ 

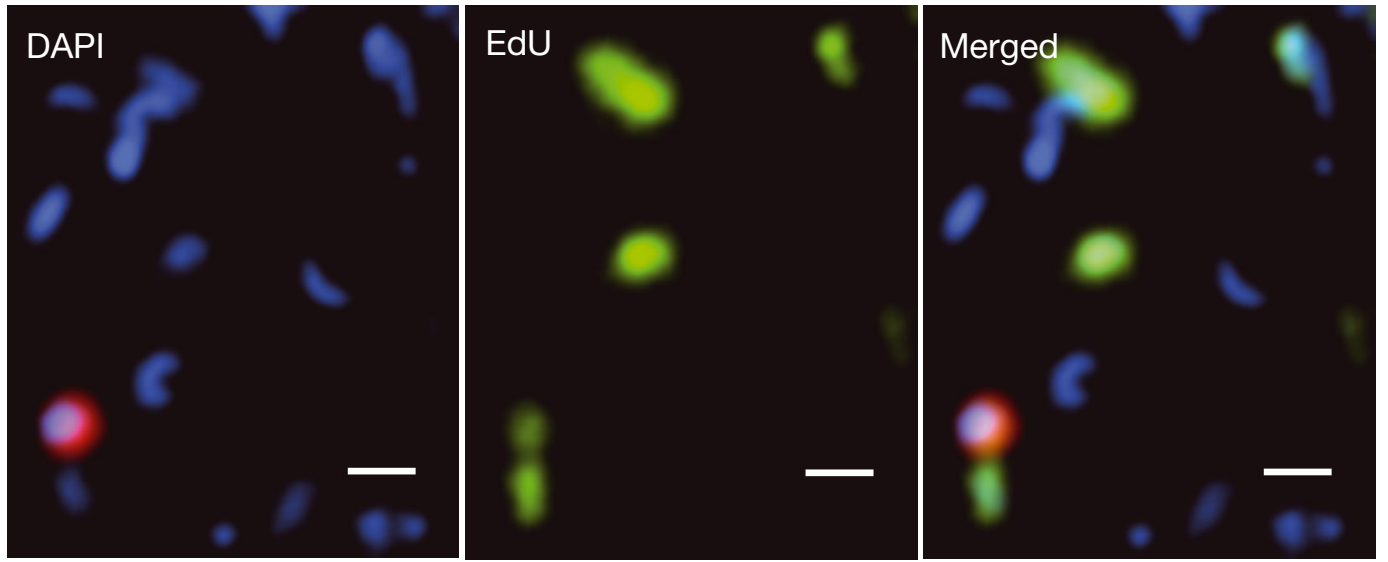

Fig. 3. Epifluorescence microscopy images of 5-ethynyl-2'-deoxyuridine (EdU)-labeled bacteria from coastal seawater. Left: blue and red combined channels show DAPI-stained bacteria including one autofluorescent picoplankter cell. Center: green channel shows only EdU-labeled cells. Right: merged image of all 3 channels. Scale bar $=1 \mu \mathrm{m}$, all panels

ments: (1) incubation with EdU for at least $3 \mathrm{~h}$ to assure higher-than-background results for individual cell signal intensity; (2) use of the 'cover-slip inversion' technique for applying the click reaction cocktail; and (3) image capture of the filter membranes (preferably with a charge-coupled device camera) within $\sim 2 \mathrm{~h}$ after click reaction processing to assure adequate DAPI and AlexaFluor-488 signal intensity. The first and third requirements are likely less critical for rapidly replicating bacteria. We emphasize that the EdU protocol in its current form is not a replacement for ${ }^{3} \mathrm{H}-\mathrm{TdR}$ microradiography. Similarly, the EdU technique is not an indicator of all 'growing' cells (e.g. those synthesizing protein or RNA), only those that are actively synthesizing DNA, which may include chromosome replication and DNA repair.

\section{Labeling in natural coastal seawater assemblages} and comparison with ${ }^{3} \mathrm{H}$-TdR microautoradiography

The EdU protocol (Fig. 1) was applied to natural bacterial assemblages collected from coastal California waters over 6 dates (see supplementary 'Materials and methods', Table S1). The percent labeled cells in EdU-amended treatments ranged from 9.2 to $62.9 \%$, while in parallel unamended controls the percent labeling ranged from 3.4 to $13.9 \%$; corrected percent labeling ranged from 4.4 to $49 \%$ (Table 1). Mean individual labeled cell signal intensities ranged from $82 \times 10^{2}$ to $423 \times 10^{2}$ relative fluorescence units (RFU) in EdU-amended treatments, while they ranged from $48 \times 10^{2}$ to $178 \times 10^{2} \mathrm{RFU}$ for the labeled cells in parallel unamended controls. Several

Table 1. Labeling in natural bacterial seawater assemblages after processing via 'click' chemistry. Cells were quantified among duplicate filters for each sample and treatment ( 10 microscopic fields per filter). Unamended controls (no 5-ethynyl2'-deoxyuridine, EdU) showed apparent background labeling from some undetermined source. 'Corrected \% labeling' shows the difference between treatments for percent labeling. Sample collection locations and environmental conditions varied (Table S1 in the Supplement)

\begin{tabular}{|c|c|c|c|c|c|c|c|c|c|}
\hline \multirow{3}{*}{ Sample } & \multicolumn{4}{|c|}{ Unamended controls } & \multicolumn{4}{|c|}{$\longrightarrow$ EdU-amended } & \multirow{3}{*}{$\begin{array}{c}\text { Corrected } \\
\% \\
\text { labeling }\end{array}$} \\
\hline & \multirow[t]{2}{*}{$\begin{array}{l}\text { Total cells } \\
\text { analyzed } \\
\text { (n) }\end{array}$} & \multirow[t]{2}{*}{$\begin{array}{l}\% \text { labeling } \\
\pm 95 \% \text { CI }\end{array}$} & \multicolumn{2}{|c|}{$\begin{array}{c}\text { Individual labeled cell } \\
\text { signal intensity } \\
\left(\times 10^{2} \mathrm{RFU}\right)\end{array}$} & \multirow[t]{2}{*}{$\begin{array}{l}\text { Total cells } \\
\text { analyzed } \\
\text { (n) }\end{array}$} & \multirow[t]{2}{*}{$\begin{array}{c}\% \text { labeling } \\
\pm 95 \% \text { CI }\end{array}$} & \multicolumn{2}{|c|}{$\begin{array}{l}\text { Individual labeled cell } \\
\text { signal intensity } \\
\left(\times 10^{2} \mathrm{RFU}\right)\end{array}$} & \\
\hline & & & Range & Median & & & Range & Median & \\
\hline SP1 & 609 & $3.4 \pm 1.1$ & $5-629$ & 16 & 1391 & $16.7 \pm 3.0$ & $2-7680$ & 116 & 13 \\
\hline $\mathrm{SP} 2^{\mathrm{a}}$ & 896 & $4.8 \pm 2.0$ & $18-656$ & 124 & 1921 & $9.2 \pm 2.4$ & $6-2821$ & 290 & 4.4 \\
\hline SP3 & 2344 & $9.2 \pm 3.4$ & $12-269$ & 39 & 2561 & $30.2 \pm 2.4$ & $12-2969$ & 112 & 21 \\
\hline SP4 & 829 & $13.9 \pm 4.5$ & $0.5-743$ & 54 & 969 & $62.9 \pm 6.8$ & $4-5884$ & 156 & 49 \\
\hline E1 & 1803 & $5.2 \pm 1.9$ & $14-629$ & 62 & 871 & $25.5 \pm 5.1$ & $11-434$ & 62 & 20 \\
\hline E2 & 739 & $9.6 \pm 4.5$ & $4-444$ & 47 & 722 & $18.8 \pm 4.4$ & $2-2971$ & 137 & 9.2 \\
\hline
\end{tabular}


Fig. 4. Literature values for percent cell labeling using tritiated thymidine $\left({ }^{3} \mathrm{H}\right.$ TdR) autoradiography (blue squares) or 5bromo-2'-deoxyuridine (BrdU) immunochemistry (orange circles), with ${ }^{3} \mathrm{H}-\mathrm{TdR}$ and 5-ethynyl-2'-deoxyuridine (EdU, green triangles) results from the current study shown for comparison. All values are for percentage of total prokaryote abundance (typically via DAPI-staining) for marine water samples (>29 PSU) with substrate incubation of 3 to $10 \mathrm{~h}$

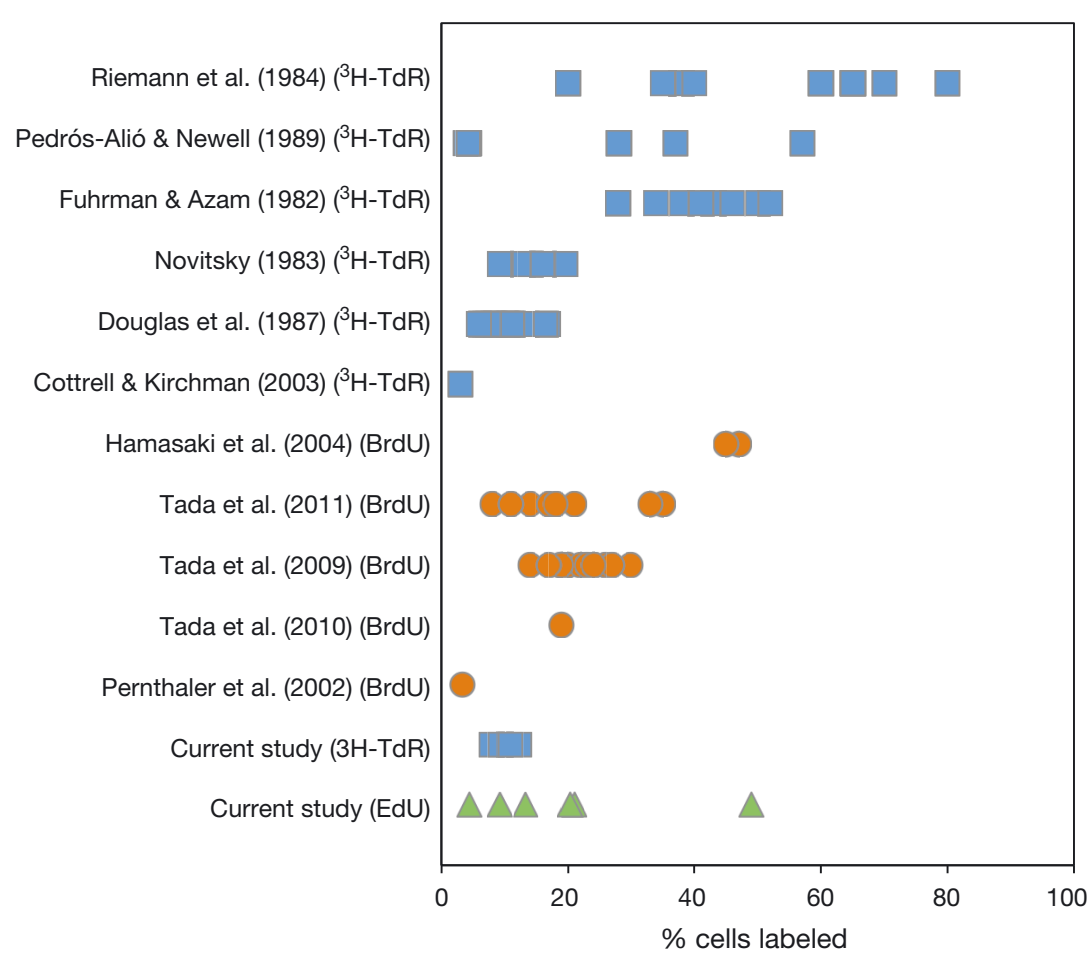

account for the percent labeling discrepancies, including differences in the substrate concentration ( $1 \mu \mathrm{M}$ for EdU and $20 \mathrm{nM}$ for ${ }^{3} \mathrm{H}-\mathrm{TdR}$ ) and incubation time ( $5 \mathrm{~h}$ for EdU and $1 \mathrm{~h}$ for ${ }^{3} \mathrm{H}-\mathrm{TdR}$ ). Nevertheless, our results for both EdU percent labeling and ${ }^{3} \mathrm{H}$-TdR percent labeling overlap with previously reported estimates of TdR incorporation in free-living marine bacteria (Fig. 4). Generally, labeling is $<50 \%$ across studies, and together the current and previous estimates demonstrate that a large and variable fraction of bacteria in natural assemblages are not synthesizing DNA during the substrate incubation period (likely a small fraction of the cell cycle) or doing so at very slow rates such that incorporated signal is below detection for our EdU protocol.

\section{Partitioning of community signal among individual cells} with limited influence from 'background' labeling.

The protocol was compared with ${ }^{3} \mathrm{H}$-TdR microradiography via parallel incubations for 4 of the 6 sampling dates. Labeled cells (reported with methodspecific controls subtracted) ranged from 9.3 to $48.9 \%$ via EdU and 7.8 to $12.3 \%$ via ${ }^{3} \mathrm{H}$-TdR microradiography (Fig. S2 in the Supplement). On a sampleby-sample basis, percent labeling was higher in EdU than in ${ }^{3} \mathrm{H}-\mathrm{TdR}$ microradiography. (An exception is sample E2, where cell labeling was equivalent.) Optimized parameters specific to each method may
Quantification of individual cell signal intensity was the basis for determining whether a cell was 'labeled,' but it also permitted quantification of an individual cell's relative contribution to total community signal. For each sample, the sum signal of all individual cells was designated as the 'community sum' or CS. We then rank ordered signals for labeled individual cells within each sample, and we plotted the CS as it accumulated progressively with decreasing cell rank (Fig. 5). This view demonstrates that a relatively low 


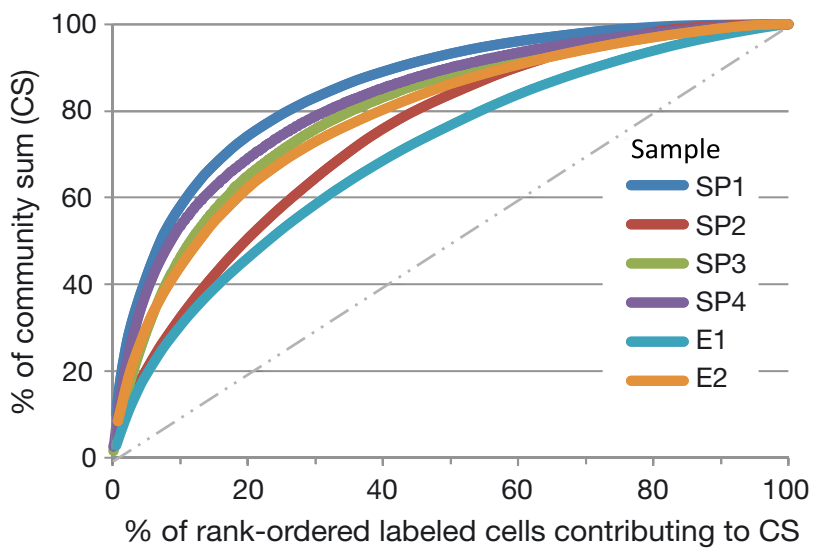

Fig. 5. 5-ethynyl-2'-deoxyuridine (EdU) signal partitioning among labeled cells within natural seawater communities. The sum EdU signal of all labeled cells within a sample ( $\mathrm{n}=$ 131 to 759 cells) was designated the community sum (CS). Shown is the relationship between rank-ordered labeled cells and the contribution of those cells to the CS in each sample, e.g. $80 \%$ of CS was comprised of $26 \%$ labeled cells in sample SP1. The 1:1 dashed-dotted line illustrates the hypothetical scenario of CS being distributed approximately evenly among all labeled cells

number of cells comprised most of the CS for each sample. For example, only 26 to $55 \%$ of the labeled cells comprised $80 \%$ of the CS across the 6 communities. The top $10 \%$ rank-ordered cells (i.e. most intensely labeled cells) comprised 32 to $58 \%$ of their respective CS (Fig. 5). The mean signals for these top $10 \%$ subcommunities were 4 - to 12 -fold higher than the mean signals for the bottom $90 \%$ subcommunities within their respective samples (data not shown).

The observed partitioning of EdU signal likely reflects physiological structure among individuals within the community (del Giorgio \& Gasol 2008). Several studies have evaluated subcommunity structure through determination of percentage active cells using various markers (i.e. probe-positive cells) and/ or through estimation of cell-specific rates, where bulk activity is divided by total cell abundance (e.g. Alonso-Sáez \& Gasol 2007). Few studies have considered the distribution of individual cell activities within bulk assemblage activity. Sintes \& Herndl (2006) determined ${ }^{3} \mathrm{H}$-leucine incorporation rates for individual bacteria and estimated their contribution to bulk incorporation rates. They found that cells with very low rates comprised $\sim 70 \%$ of labeled cells but contributed only $25 \%$ to the bulk activity, while only $2 \%$ of labeled cells had high incorporation rates but accounted for $16 \%$ of bulk activity. Similarly, Yokokawa et al. (2012) were able to differentiate Bacteria and Archaea single cell leucine incorporation rates. Meanwhile, Nikrad et al. (2012) measured silver grain cluster areas of ${ }^{3} \mathrm{H}$-leucine-positive bacteria and found that $\sim 22 \%$ were highly active, though their contribution to the total community signal was not determined. Our EdU results are broadly consistent in that a small fraction of labeled cells accounted for a disproportionately high portion of total community EdU signal. With this, one must also consider the range of maximal growth rates that likely occurs among various bacterial taxa adapted to various nutrient regimes in their (micro) environments. Still, the observations support the hypothesis that variance in the proportions of cells in different physiological states within assemblages may be a critical mechanism underpinning bulk patterns of bacterial metabolism in seawater (del Giorgio \& Gasol 2008).

\section{Cellular localization of incorporated EdU label}

We observed intracellular variability in localization of the EdU signal and colocalization with the DAPI signal. Among 3 bacterial isolates growing in enriched seawater media, distinct spots and patches were visible within individual cells of Vibrio corallillyticus and Flexibacter SBD8 (Fig. 6a,b), while the EdU signal within Roseobacter BBAT1 cells was distributed more homogenously (not shown). In general, locations that displayed a diminished signal in the blue channel displayed a highly intense EdU signal in the green channel. Likewise, cells displaying a dim blue signal homogenously throughout the cell displayed an extremely intense green signal over the same cell area.

Variability in intracellular signal localization was also observed among natural bacteria assemblages. Eighty-seven percent of labeled cells displayed a homogeneously distributed EdU signal that colocalized with a homogenously distributed DAPI signal (Table 2). Thirteen percent of labeled cells displayed DAPI and EdU signals that were non-colocalized, and among these, 7 patterns were identified (Table 2). We operationally defined these to be 'dividing' cells and, along with dividing cells stained only with DAPI (i.e. non-EdU labeled), we quantified their relative occurrence among 5 sampling dates. Many dividing cells $(42 \%)$ were stained with DAPI only (Fig. 6c). A substantial portion (24\%) displayed a 'single DAPI, double EdU' (SDDE) pattern. Within these SDDE cells, the largest subset $(75 \%)$ displayed an ovoidshaped DAPI signal with an EdU signal at both poles (Fig. 6c, right). Another SDDE subset (11\%) displayed a longer rod-shaped DAPI signal with an EdU signal at both poles. 


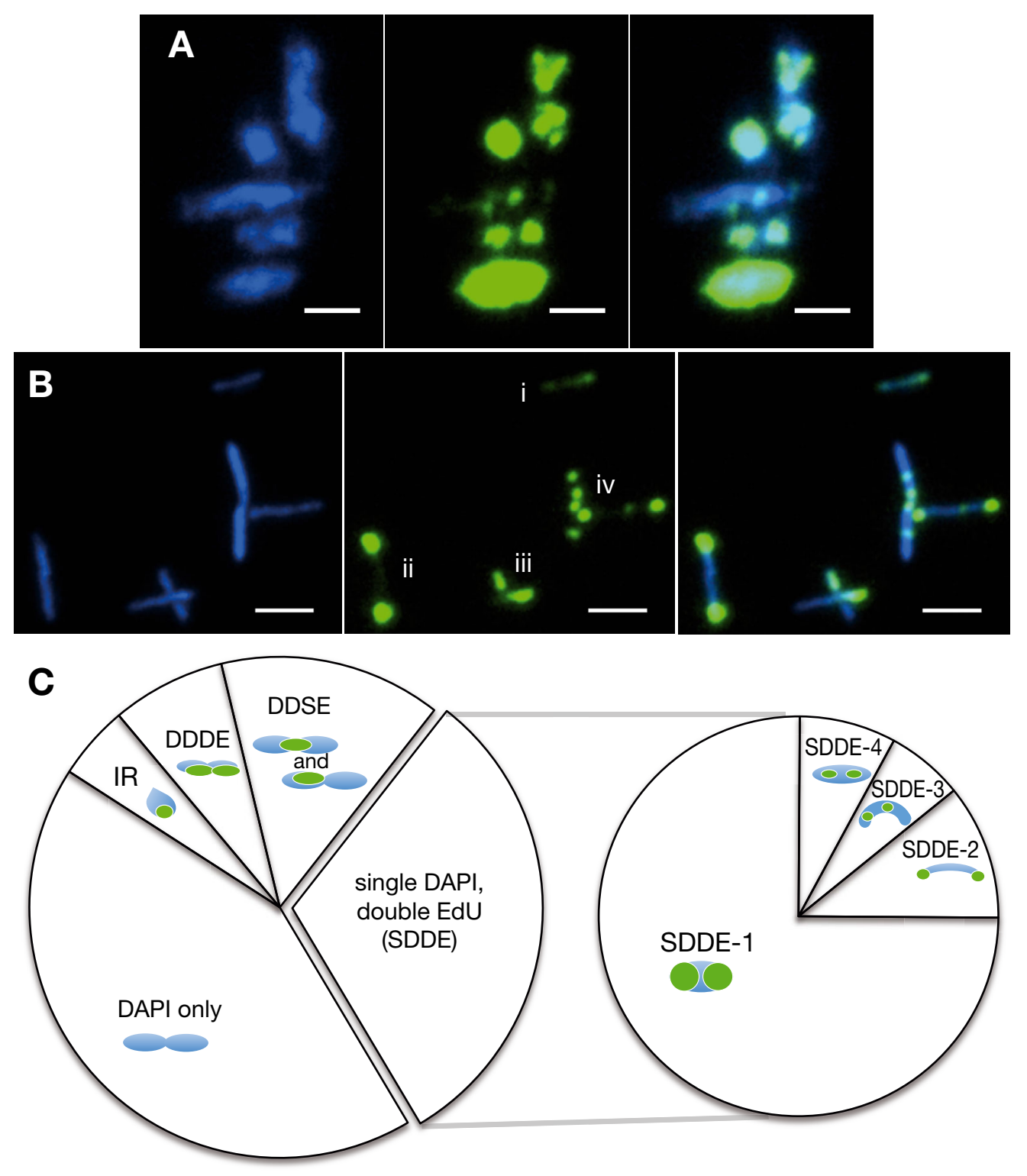

Fig. 6. Localization of signal in 5-ethynyl-2'-deoxyuridine (EdU)-labeled bacteria. (A) Cultured Vibrio corallilyticus cells showing both patchy and homogenous EdU localization. (B) Cultured Flexibacter sp. SBD8 cells displaying several distinct patterns, including (i) relatively even EdU distribution throughout cell, (ii) EdU at both poles, (iii) at one pole, and (iv) at multiple midcell sites. The images show the blue DAPI signal (left panel), green EdU signal (middle), and combined signals (right). Scale bar $=1 \mu \mathrm{m} .(\mathrm{C}$, left) Distribution of localization patterns among individual dividing cells $(\mathrm{n}=275)$ among natural assemblages in 5 seawater samples. Abbreviations are IR for irregular pattern; DDDE for double DAPI, double EdU; DDSE for double DAPI, single EdU; and SDDE for single DAPI, double EdU. Eighty-four dividing cells $(31 \%)$ were categorized as SDDE, which displayed 4 distinct patterns $(C$, right). Example images for each pattern are shown in Table 2

The EdU and DAPI signal localization patterns are broadly consistent with conceptual models of DNA replication and chromosome replication in Escherichia coli and Bacillus subtilis (Lewis \& Errington 1997, Draper \& Gober 2002, Wang et al. 2013). When replication is initiated in $B$. subtilis, DNA strands are separated near the origin of replication region (oriC) of the chromosome and each strand acts as a template for synthesis of a complementary nascent strand. The duplicated oriC regions rapidly migrate away from each other moving from mid-cell toward opposite cell poles while the bulk of the not-yet-replicated chromosome remains mid-cell. After the chromosome is completely replicated and the chromosomal dimers are resolved into each daughter cell, membrane septation occurs mid-cell with eventual complete cell division. 
Table 2. Intracellular 5-ethynyl-2'-deoxyuridine (EdU) localization patterns in natural assemblages and potential causes for each pattern. Two patterns occurred in singlet cells while all others occurred in operationally defined 'dividing' cells. DAPI $=$ 4', 6-diamidino-2-phenylindole. ${ }^{*}$ Most labeled cells $(87 \%)$ displayed this pattern

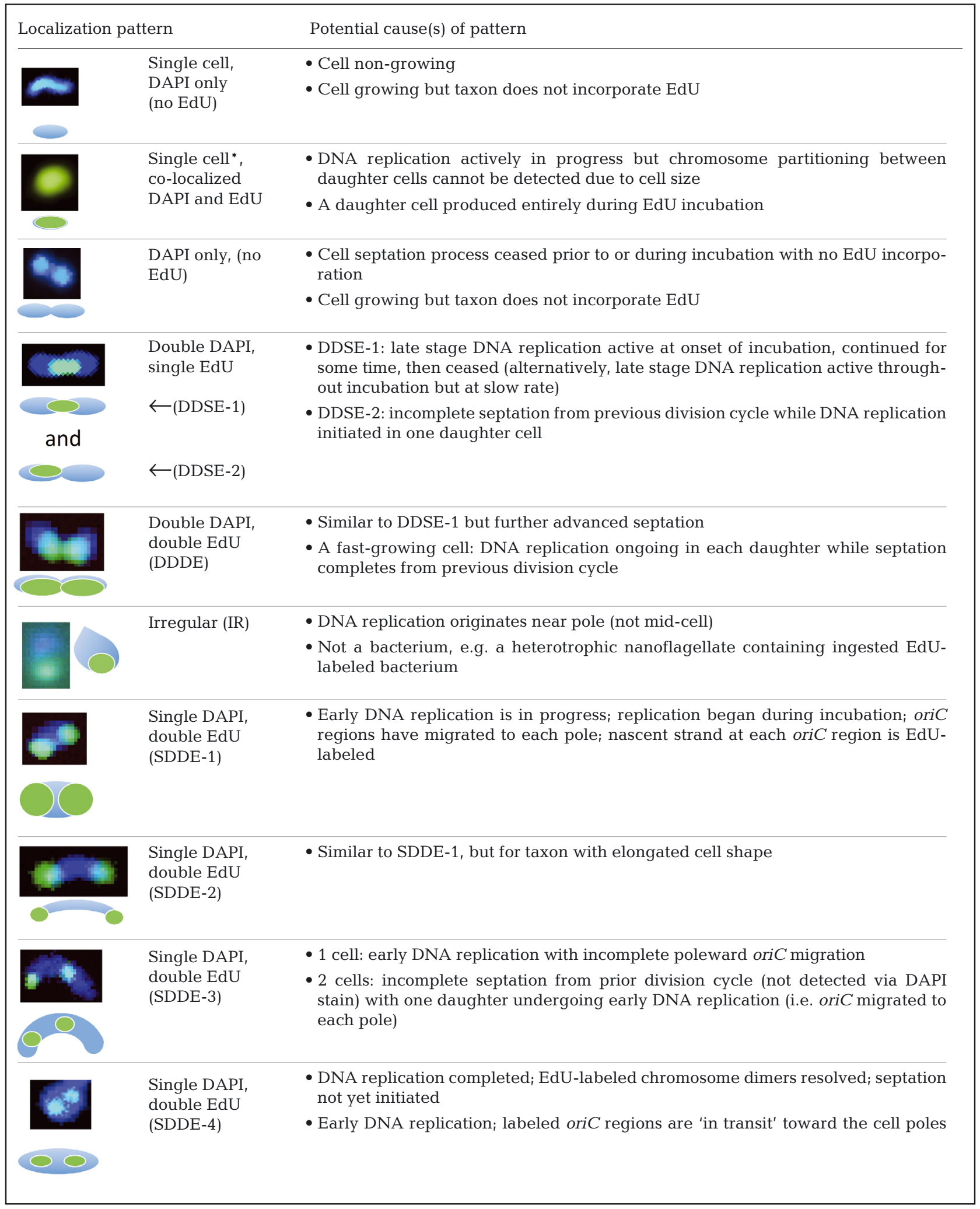


Given this background, we interpreted each EdU localization pattern (Table 2, right column) with the assumption that EdU is incorporated into nascent strands throughout the DNA replication process. For example, we suggest that the SDDE-1 pattern reflects an early stage of DNA replication wherein duplicated oriC regions have migrated to each cell pole and the nascent strand at each oriC region is EdU-labeled. In this case, replication likely began during incubation but halted when the cells were fixed. Similarly, in the cultured Flexibacter SBD8 isolate, some non-septated cells displayed an EdU signal at the far poles (Fig. 6b, ii), which may also reflect rapid poleward partitioning of EdU-labeled oriC regions.

While our interpretations of the intracellular localization patterns are putative, the EdU technique provides an advantage over ${ }^{3} \mathrm{H}$-TdR microautoradiography in that quantification of silver crystal cluster size via the latter method does not provide sufficient resolution to observe intracellular distribution of ${ }^{3} \mathrm{H}$ TdR-labeled DNA. Furthermore, the EdU technique may aid in quantification of the frequency of dividing cells (FDC) which has been used to estimate natural assemblage growth rates (Hagström et al. 1979, Riemann et al. 1984). Mid-cell septa are an observable characteristic of dividing bacteria, and the typical methodological approach for FDC estimates uses quantification of DAPI-stained or acridine orange (AO)-stained cells (e.g. Samo et al. 2012). The EdU approach may provide an alternative method; specifically, the SDDE pattern would not be recognized as 'dividing' via DAPI or AO. Indeed, among 1500 cells analyzed here, the FDC was $7.5 \%$ when all dividing cell categories were included, but was $5.2 \%$ when the SDDE category was excluded.

\section{Toward individual-based ecophysiology}

The EdU-'click' chemistry approach provides a more time-efficient method for detecting and quantifying growing cells engaged in rapid DNA synthesis in a spatial-temporal context. The method should also enable studies of chromosomal segregation in model organisms such as B. subtilis. It complements other methods that characterize replicating cells in mixed assemblages, e.g. immunocapture of BrdUlabeled DNA with subsequent analysis of genomic content (Mou et al. 2008). The combination of these approaches may be useful for addressing long-standing questions on growth physiology, e.g. what portion of bacteria are active in what detection time frames in relation to dissolved organic matter composition? Future improvements that quantify detection limits and EdU:TdR incorporation ratios, among other factors, should enable the conversion of an EdU fluorescence signal into individual cell carbon production rates. Furthermore, EdU incorporation combined with fluorescence in situ hybridization should enable estimates of taxa-specific in situ replication rates at the individual cell level.

Acknowledgements. We thank J. Nguyen, X. Mayali, B. Pedler, M. Garren, and K. Rypien for assistance and helpful discussions. We also thank N. Wilson and the crew of R/V 'Robert Gordon Sproul' for assistance in sample collection. This research was funded by the Gordon and Betty Moore Foundation through Grant GBMF 2758 to F.A.; by the National Science Foundation grants (OCE0648116 and OCE1036613); by the Global Environment Facility Coral Reef Targeted Research program; by University of California Ship Funds; and by an NSF Graduate Student Research Fellowship to S.S..

\section{LITERATURE CITED}

Alonso-Sáez L, Gasol JM (2007) Seasonal variations in the contributions of different bacterial groups to the uptake of low-molecular-weight compounds in northwestern Mediterranean coastal waters. Appl Environ Microbiol 73:3528-3535

Azam F, Malfatti F (2007) Microbial structuring of marine ecosystems. Nat Rev Microbiol 5:782-791

Cottrell MT, Kirchman DL (2003) Contribution of major bacterial groups to bacterial biomass production (thymidine and leucine incorporation) in the Delaware estuary. Limnol Oceanogr 48:168-178

del Giorgio PA, Gasol JM (2008) Physiological structure and single-cell activity in marine bacterioplankton. In: Kirchman DL (ed) Microbial ecology of the oceans, 2nd edn. Wiley-Blackwell, Hoboken, NJ, p 243-298

> Douglas DJ, Novitsky JA, Fournier RO (1987) Microautoradiography-based enumeration of bacteria with estimates of thymidine-specific growth and production rates. Mar Ecol Prog Ser 36:91-99

> Draper GC, Gober JW (2002) Bacterial chromosome segregation. Annu Rev Microbiol 56:567-597

Fuhrman JA, Azam F (1982) Thymidine incorporation as a measure of heterotrophic bacterioplankton production in marine surface waters: evaluation and field results. Mar Biol 66:109-120

Hagström A, Larsson U, Horstedt P, Normark S (1979) Frequency of dividing cells, a new approach to the determination of bacterial growth rates in aquatic environments. Appl Environ Microbiol 37:805-812

> Hamasaki K, Long RA, Azam F (2004) Individual cell growth rates of marine bacteria, measured by bromodeoxyuridine incorporation. Aquat Microb Ecol 35:217-227

Kolb HC, Finn MG, Sharpless KB (2001) Click chemistry: diverse chemical function from a few good reactions. Angew Chem Int Ed 40:2004-2021

Lewis PJ, Errington J (1997) Direct evidence for active segregation of oriC regions of the Bacillus subtilis chromo- 
some and co-localization with the SpoOJ partitioning protein. Mol Microbiol 25:945-954

Longnecker K, Wilson MJ, Sherr EB, Sherr BF (2010) Effect of top-down control on cell-specific activity and diversity of active marine bacterioplankton. Aquat Microb Ecol 58: 153-165

Mou X, Sun S, Edwards RA, Hodson RE, Moran MA (2008) Bacterial carbon processing by generalist species in the coastal ocean. Nature 451:708-711

Nikrad MP, Cottrell MT, Kirchman DL (2012) Abundance and single-cell activity of heterotrophic bacterial groups in the western Arctic Ocean in summer and winter. Appl Environ Microbiol 78:2402-2409

Noble RT, Fuhrman JA (1998) Use of SYBR Green I for rapid epifluorescence counts of marine viruses and bacteria. Aquat Microb Ecol 14:113-118

Novitsky JA (1983) Heterotrophic activity throughout a vertical profile of seawater and sediment in Halifax Harbor, Canada. Appl Environ Microbiol 45:1753-1760

$>$ Pedros-Alio C, Newell SY (1989) Microautoradiographic study of thymidine uptake in brackish waters around Sapelo Island, Georgia, USA. Mar Ecol Prog Ser 55: 83-94

Pernthaler A, Pernthaler J, Schattenhofer M, Amann R (2002) Identification of DNA-synthesizing bacterial cells in coastal North Sea plankton. Appl Environ Microbiol 68:5728-5736

Riemann B, Nielsen P, Jeppesen M, Marcussen B, Fuhrman JA (1984) Diel changes in bacterial biomass and growth rates in coastal environments, determined by means of thymidine incorporation into DNA, frequency of dividing cells (FDC), and microautoradiography. Mar Ecol Prog Ser 17:227-235

Rostovtsev VV, Green LG, Fokin VV, Sharpless KB (2002) A stepwise Huisgen cycloaddition process: copper(I)-catalyzed regioselective 'ligation' of azides and terminal alkynes. Angew Chem Int Ed 41:2596-2599

Salic A, Mitchison TJ (2008) A chemical method for fast and sensitive detection of DNA synthesis in vivo. Proc Natl

Editorial responsibility: Jed Fuhrman,

Los Angeles, California, USA
Acad Sci USA 105:2415-2420

Samo TJ, Pedler BE, Ball GI, Pasulka AL and others (2012) Microbial distribution and activity across a water mass frontal zone in the California Current Ecosystem. J Plankton Res 34:802-814

Sintes E, Herndl GJ (2006) Quantifying substrate uptake by individual cells of marine bacterioplankton by catalyzed reporter deposition fluorescence in situ hybridization combined with micro autoradiography. Appl Environ Microbiol 72:7022-7028

Steward GF, Azam F (1999) Bromodeoxyuridine as an alternative to ${ }^{3} \mathrm{H}$-thymidine for measuring bacterial productivity in aquatic samples. Aquat Microb Ecol 19:57-66

Tada Y, Taniguchi A, Hamasaki K (2009) Phylotype-specific productivity of marine bacterial populations in eutrophic seawater, as revealed by bromodeoxyuridine immunocytochemistry combined with fluorescence in situ hybridization. Microbes Environ 24:315-321

Tada Y, Taniguchi A, Hamasaki K (2010) Phylotype-specific growth rates of marine bacteria measured by bromodeoxyuridine immunocytochemistry and fluorescence in situ hybridization. Aquat Microb Ecol 59:229-238

> Tada Y, Taniguchi A, Nagao I, Miki T, Uematsu M, Tsuda A, Hamasaki K (2011) Differing growth responses of major phylogenetic groups of marine bacteria to natural phytoplankton blooms in the western North Pacific Ocean. Appl Environ Microbiol 77:4055-4065

> Udwary DW, Zeigler L, Asolkar RN, Singan V and others (2007) Genome sequencing reveals complex secondary metabolome in the marine actinomycete Salinispora tropica. Proc Natl Acad Sci USA 104:10376-10381

Wang X, Llopis PM, Rudner DZ (2013) Organization and segregation of bacterial chromosomes. Nat Rev Genet 14:191-203

> Yokokawa T, Sintes E, De Corte D, Olbrich K, Herndl GJ (2012) Differentiating leucine incorporation of Archaea and Bacteria throughout the water column of the eastern Atlantic using metabolic inhibitors. Aquat Microb Ecol 66:247-256

Submitted: December 16, 2013; Accepted: March 31, 2014 Proofs received from author(s): June 11, 2014 